\title{
ANALISIS ANGGARAN DAN PENGENDALIAN BIAYA TERHADAP PENINGKATAN EFISENSI BIAYA
}

\author{
Kros dan Iriyadi
}

\author{
SekolahTinggi Ilmu Ekonomi Kesatuan
}

\begin{abstract}
A company needs a perfect and good planning for preparing a start at the company activites. A good planning need to give a good feed back that could give a trigger for an appearence of a conductive good working atmosphere from the budget. A good company must be able to make a sistematic and infomative budge calculation that help management on controling the costs.

This research purpose is to know how a company make their operational budget and to know how a company control every deviantions that happens from practice. The company that the writer studied is PT. Lieyantra Sukses Mandiri.

To get to know the role of a budget as a company operational cost control device, the writer is using analysis report form or a simple analysis deviantion that compare between budget and the realization, where the deviantion of a operational budget on budget stations found. But, in this case there's no increase on the company income so that the company go through a smaller income compare from the last year.

The decision that the company make on implementing company activities has a huge effect on the company income even outcome, therefore before making a decision, first the management had to make a good planning.

The budget that has been set should be set as expected, because of the lack of control from the management against the realization therefore a deviantion that adverse the company happened.
\end{abstract}

Keywords : Budget analysis, Budget control

\section{PENDAHULUAN}

Di era sekarang ini banyak sekali perusahaan yang berkembang, perusahaan seringkali mencari peluang bisnis apa yang tepat untuk dijalankan sekarang ini, salah satunya ialah perusahaan jasa. Jasa seringkali dibutuhkan untuk melayani kebutuhan yang terabaikan. Salah satu perusahaan jasa yang berkembang ialah perusahaan alat-alat berat, 
peluang dibidang ini cukup besar dan menjanjikan di masa depan karena jarang ada perusahaan yang menjalani bisnis ini mengingat bahwa modal yang dibutuhkan sangat besar, sulit mencari proyek untuk bekerja sama, dan sulit mendapatkan pendanaan pinjaman/leasing.

Agar perusahaan jasa di bidang penyewaan alat-alat berat ini terus berjalan, maka dibutuhkan analisis pengendalian biaya yaitu upaya memelihara ketentuan-ketentuan yang telah ditetapkan agar tidak terjadi penyimpangan dalam operasional. Hal ini dikarenakan bisnis penyewaan alat-alat berat merupakan bisnis yang langsung terjun ke proyek/lapangan sehingga biaya-biaya yang ada di proyek tersebut harus dikontrol agar laba yang dihasilkan maksimal.

Dalam usaha untuk menekan biaya perusahaan yang tinggi, perlu adanya efisiensi pada biaya operasional, sehingga beban biaya operasional pada perusahaan dapat diminimalisasi, dan perencanaan yang telah ditetepkan perusahaan akan tercapai. Perencanaan merupakan proses tindakan - tindakan yang akan dilakukan di masa yang akan datang untuk mencapai tujuan yang diharapkan. Perencaaan membantu perusahaan dalam mencapai tujuan, memanfaatkan peluang, dan meminimalkan resiko yang akan terjadi. Sedangkan pengendalian merupakan proses yang digunakan oleh manajemen agar para pelaksana bekerja dengan efektif dan efisien dalam rangka mencapai tujuan perusahaan.

Keberhasilan pelaksanaan proses perencanaan dan pengendalian ditentukan oleh suatu alat yang memadai dan berfungsi sebagai tolak ukur, yaitu anggaran. Anggaran adalah rencana rinci tentang perolehan dan penggunaan sumber daya keuangan dan sumber daya lainnya untuk suatu periode tertentu. Dengan adanya anggaran, biaya - biaya yang terjadi dapat dibandingkan dengan biaya - biaya yang direncanakan, untuk itu perlu di analisis mengapa terjadi penyimpangan dan akhirnya dapat dilakukan tindakan koreksi secara cepat.

Anggaran lazim disebut perencanaan dan pengendalian laba, yaitu proses yang ditunjukan untuk membantu manajemen dalm perencanaan dan pengendalian secara efektif, rencana tentang kegiatan perusahaan yang mencakup berbagai kegiatan operasional yang saling berkaitan dan saling mempengaruhi satu sama lain sebagai pedoman dalam mencapai tujuan dan sasaran suatu organisasi. Anggaran dapat membantu manajer dalam memilih mana tujuan yang dapat dilaksanakan dan mana yang baik.

Pengendalian Biaya bertanggung jawab dalam menelusuri biaya/aliran dana terhadap anggaran/budget yang telah ditetapkan. Kegiatan pengendalian biaya sangat erat hubungannya dengan fungsifungsi manajemen lainnya, oleh karena itu kegiatan pengendalian ini dapat dilihat apakah tujuan kegiatan yang telah direncanakan dapat dicapai dalam pelaksaan secara riil. pengendalian biaya adalah proses atau usaha yang sistematis dalam penetapan standar pelaksaan dengan tujuan perencanaan, sistem informasi umpan balik, membandingkan pelaksaan nyata dengan perencanaan menentukan dan mengatur penyimpangan-penyimpangan serta melakukan koreksi perbaikan sesuai 
dengan rencana yang telah ditetapkan, sehingga tujuan tercapai secara efektif dan effisien dalam pengunaan biaya.

\section{METODE PENELITIAN}

Dalam teknik pengumpulan data yang saya lakukan untuk menyusun seminar ini adalah dengan menggunakan 2 metode, yaitu :

1. Metode studi pustaka

Adalah teknik mengumpulkan data dengan cara membaca dan mempelajari data yang berhubungan dengan topik penelitian yang dibahas. Teknik ini dimaksudkan untuk memperoleh landasan teoritis yang mempunyai kaitan dengan permasalahan yang akan dibahas. Data yang diperoleh dari teknik ini sudah barang tentu tidak langsung didapat dari sumbernya langsung, karena itulah data dari teknik ini merupakan data sekunder. Dalam studi pustaka pada perusahaan data yang di berikan oleh Finance Controler apakah rencana anggaran yang sudah di tetapkan dapat terleasisai dengan baik di lapangan, dan bagaimana penggunaan anggaran sehingga biaya yang di timbulkan tidak melebihi anggaran yang telah di buat oleh manajemen untuk dapat meningkatkan efisiensi biaya pada perusahaan.

2. Metode studi lapangan

Adalah teknik pengumpulan data yang dilakukan dengan mengadakan penelitian langsung ke perusahaan serta menganalisa data yang tersedia di lapangan dan prosedur pelaksanaan kegiatan yang ditetapkan dan dijalankan sesuai dengan masalah yang akan dibahas sehingga diperoleh data primer. Analisa data yang tersedia di lapangan.

\section{HASIL DAN PEMBAHASAN}

Dalam penyusunan anggaran diperlukan suatu unit organisasi yang mengkoordinasikan berbagai jenis usulan anggaran dari berbagai pusat pertanggungjawaban untuk kemudian disusun menjadi rancangan anggaran induk. Komite ini mereview ataupun menyesuaikan anggaran tersebut, unit organisasi ini disebut dengan komite anggaran. Unit organisasi ini hanya dibentuk pada saat proses penyusunan anggaran saja. Jika proses penyusunan anggaran perusahaan telah selesai, komite anggaran menjadi tidak berfungsi dan fungsi pengendalian pelaksanaan anggaran diserahkan kepada uni organisasi perusahaan.

Dalam bisnis modern manajemen harus selalu memandang dan merencanakan masa depan. Selain data historis, manajemen memerlukan informasi lingkungan eksternal dan informasi lainnya yang akan 
mempengaruhi perusahaan pada masa depan.

Perencanaan adalah memilih beberapa alternatif yang memungkinkan untuk dilaksanakan di masa depan dengan mempertimbangkan tujuan perusahaan serta sumber-sumber ekonomi yang dimiliki dan kendala-kendala yang dihadapi di masa yang akan daang. Perencanaan yang disusun oleh suatu perusahaan sekaigus digunakan sebagai dasar untuk pengendalian, yaitu menilai efektifitas dan efiseinsi yang dicapai perusahaan.

Oleh karena itu agar perusahaan mempunyai rencana strategis yang mencakup rumusan dan tujuan yang hendak dicapai oleh perusahaan dalam jangka waktu 5 (lima) tahun mendatang, maka perlu menyusun rencana jangka panjang.

Rencana ini kemudian dijabarkan secara tahunan ke dalam Rencana Kerja dan Anggaran Perusahaan.

Anggaran tahunan harus disusun dengan memperhatkan :

- Realisasi kegiatan usaha I tahun berjalan

- Estimasi hasil kegiatan yang dapat dicapai pada semester II tahun berjalan

- Rencana jangka panjang

- Petimbangan penting lainnya.

Anngaran tahun harus mencakup anggaran / proyeksi berikut ini :

- Anggaran perhitungan Rugi Laba

- Anggaran Peredaran Kas

- Proyeksi Sumber dan Penggunaan Dana

Anggaran harus disusun melalui koordinasi antara seluruh pejabat dan staf lingkungan perusahaan yang terdiri dari Direksi dan KepalaKepala Bagian yang terkait dengan penyusunan anggaran.

Penyusunan anggaran harus menggunakan metode accrual, sejalan dengan dasar akuntansi yang danut dalam penyusunan laporan keuangan.

Anggaran tahunan hrus mendapat pengesahan dari Badan Pengawas terlebih dahulu seblum dilaksanakan. Jika anggaran yang diajukan tidak disahkan Badan Pengawas sampai dengan batas waktu yang ditentukan, maka perusahaan menggunakan anggaran yang paling akhir yang disahan.

Penyusunan anggaran adalah proses pengoperasionalan rencana dalam bentuk pengkuantifikasian, biasanya dalam unit moneter untuk kurun waktu tertentu. Hasil dari penyusunan anggaran adalah anggaran. Anggaran merupakan renacn a yang diungkapkan secara kuantitatif dalam unit moneter untuk periode satu tahun. Program atau strategic plan yang telah disetujui pada tahap seelumnya, merupakan titik awal dalam 
mempersiapkan anggaran.

Anggaran menunjukan jabaran dari program dengan menggunakan informasi terkini. Dalam anggaran operasional, program dihubungkan dengan pusat pertanggungjawaban, bukannya program secara individual. Biaya- biaya yang ditargerkan oleh setiap Manajer atau Kepala Bagian yang bertanggungjawab terhadap sebuah program atau bagian dari program.

\section{PEMBAHASAN PENELITIAN}

Proses penyusunan anggaran operasional pada dasarnya merupakan suatu proses negosiasi antara manajer pusat pertanggungjawaban dan atasannya. Hasil dari proses negosiasi adalah persetujuan tentang perkiraan pendapatan dan biaya yang akan terjadi selama satu tahun, untuk pusat penatapan dan biaya.

Bussiness Budget adalah suatu "financial plan". Kata utama adalah plan. Perusahaan yang berkecenderungan memandang ke depan akan selalu memikirkan apa yang mungkin dlakukan pada masa yang akan datang. Sehingga dalam pelaksanaannya, perusahaan ini tinggal berpegang pada semua rencana yang telah disusun sebelumnya untuk dilaksanakan sesuai dengan rencana yang sudah ada karena perusahaan sebelumnya telah menyusun dengan matang. Karena itu Heckerts dan Willson mengatakan bahwa relevansi utama dari Bussiness Budgeting adalah dapat ditentukannya kegiatan yang paling profitable yang akan dilakukan.

Relevansi yang lain adalah membantu manajemen dalam mengelola perusahaan. Manajemen harus mengambil keputusan yang paling menguntungkan perusahaan. Anggaran mempunyai fungsi yang pada dasarnya sama, yaitu dalam hal planning, coordinating dan control.

Salah satu aspek pengelolaan Perusahaan Daerah Air Minum yang sehat adalah dengan anggaran produksi dan keuangan perusahaan yang sesuai dengan fungsi dan peranan dari Perusahaan.

Anggaran operasional tahun 2013 disusun sebagai pedoman bagi rencana pengembangan perusahaan tahun 2013, yang dibuat secara mendasar menyeluruh dan berkesinambungan dengan memperhatikan potensi dan kendala yang ada pada perusahaan dan lingkungannya dengan mengacu kepada coorporate plan sebagai pedoman bagi rencana pengembangan perusahaan lima tahun kedepan.

Karena sulitnya mengendalikan suatu kegiatan perusahaan, anggaran sebagai tool of control dapat dijadikan dengan realisasi, perbedaan antara keduanya merupakan penyimpangan.

Dalam hal biaya atau cost, maka jika biaya operasional realisasinya lebih besar dari anggaran maka dianggap tidak efisien, sebaliknya jika biaya operasional realisasinya lebih rendah maka dianggap efisien. Untuk mengetahui masing-masing penyebab penyimpangan biaya operasional dapat dianalisis ke masing-masing pos atau perkiraan sekaligus dapat diketahui, maka penyimpangan tersebut di analisis. Yang efisien di 
analisis untuk dijadikan contoh, sedangkan jika tidak efisien di analisis agar dapat dihindari di masa yang akan datang.

Tabel 4.2

Perbandingan Antara Anggaran Biaya Alat Berat dan Realisasi Biaya

Alat Berat Tahun 2013

\begin{tabular}{|l|c|c|c|}
\hline \multicolumn{1}{|c|}{ Biaya } & Anggaran & Realisasi & $\%$ \\
\hline Biaya Pegawai & 882.744 .738 & 860.799 .733 & $102,02 \%$ \\
\hline Biaya Oli & 54.000 .000 & 40.381 .935 & $74,78 \%$ \\
\hline Biaya Leasing & 4.886 .737 .816 & 4.295 .236918 & $87,90 \%$ \\
\hline Biaya Solar & 2.640 .000 .000 & 2.896 .170 .798 & $109,70 \%$ \\
\hline $\begin{array}{l}\text { Rupa-Rupa } \\
\text { Biaya }\end{array}$ & 2.029 .127 .442 & 2.946 .604 .569 & $145,22 \%$ \\
\hline Jumlah & 11.014 .609 .996 & 11.382 .812 .018 & $103,34 \%$ \\
& & & \\
\hline
\end{tabular}

Dalam menganalisa dan mengevaluasi selisih untuk menentukan sebab yang mendasarinya, ada beberapa kemungkinan yang perlu dipertimbangkan sebagai berikut:

1. Selisih disebabkan oleh kesalahan laporan. Sasaran yang direncanakan atau dianggarkan dan data aktual yang disediakan oleh bagian akutansi harus diperiksa kebenarannya.

2. Selisih disebabkan oleh keputusan khusus manajemen. Untuk meningkatkan efisiensi atau untuk menghadapi kemungkinan tertentu, manajemen sering membuat keputusan yang menyebabkan adanya selisih. Sebagai contoh, diputuskan untuk perubahan system lembur menjadi shiff, atau untuk penggantian alat khusus yang tidak direncanakan sebelumnya. Keputusan seperti itu harus diidentifikasi, sekali diidentifikasi, biasanya 
mereka tidak memerlukan penelitian lebih lanjut bila keputusan telah dibuat, telah disadari adanya penyimpangan dari rencana.

3. Banyak selisih yang tidak dapat dijelaskan dalam hal dampak dari faktor yang tidak dapat dikendalikan yang diidentifikasi. Misalnya seperti kerugian karena terjadi kerusakan mesin pompa air.

4. Selisih yang tidak diketahui penyebabnya harus menjadi perhatian utama dan harus diselidiki secara teliti. Dengan kata lain, manajer harus memberikan perhatian khusus kepada selisih yang membutuhkan penjelasan. Ini adalah pengecualian yang biasanya memerlukan tindak lanjut.

5. Karena sulitnya mengendalikan suatu kegiatan perusahaan, anggaran sebagai tool of control dapat dijadikan alat untuk melakukan pengawasan dan pengendalian terhadap biaya operasional. Dengan anggaran maka standar kerja yang ada dapat dibandingkan dengan realisasi, perbedaan antar keduanya merupakan penyimpangan.

6. Dalam hal biaya atau cost, maka jika biaya operasional realisasinya lebih besar dari anggaran maka dianggap tidak efisien, sebaliknya jika biaya operasional realisasinya lebih rendah maka dianggap efisien. Untuk mengetahui masingmasing penyebab penyimpangan biaya operasional dapat dianalisis ke masing-masing pos atau perkiraan sekaligus dapat diketahui siap penanggungjawabannya. Dari perbedaan efisien atau tidak efisien pada biaya operasional, maka kedua jenis penyimpangan tersebut dianalisis. Yang efisien dianalisis untuk dijadikan contoh, sedangkan jika tidak efisien dianalisis agar dapat dihindari di masa yang akan datang.

7. Dari hasil laporan realisasi tahun 2013 yang dimiliki perusahaan, maka dapat diketahui bahwa pos-pos yang mengalami penyimpangan yang merugikan perusahaan adalah dari pos biaya operasional, dimana perusahaan harus mengendalikan biaya alat berat antara lain: biaya solar, biaya gaji karyawan, biaya pemeliharaan alat berat, biaya penyusutan.

\section{SIMPULAN}

Berdasarkan hasil pembahasan yang telah dibuat maka penulis mencari kesimpulan pada PT. Lieyantra Sukses Mandiri adalah sebagai berikut:

1. PT. Lieyantra Sukses Mandiri dalam membuat anggarannya menggunakan metode bottom up, yaitu dimana semua unit kerja secara teknis membuat anggaran kerjanya masing-masing yang kemudian akan diajukan kembali kepada tim komisi anggaran, untuk dibahas lebih lanjut dan mengevaluasi setiap rencana 
anggaran yang telah dibuat. Komisi anggaran yang mengevaluasi setiap rencana anggaran itu terdiri dari Direktur utama, Direktur umum, Finance Controler sebagai Ketua merangkap anggota, Project manager sebagai sekretaris merangkap anggota, Accounting sebagai anggota, dan Finance sebagai anggota.

PT. Lieyantra Sukses Mandiri dalam pelaksanaan pengendalian biaya operasionalnya menggunakan cara preventif dan kuratif.

Setelah dianalisa, ditemukan bahwa perusahaan masih menggunakan anggaran merata untuk setiap pos-pos rutin sehingga tidak dapat dihindari dan diantisipasi apabila terdapat kenaikan signifikan pada tahun anggaran 2013 adalah anggaran pegawai, anggaran pemakaian solar, anggaran rupa - rupa biaya operasi, dimana terdapat ketidakefisienan yang sangat menonjol, realisasi yang di lakukan melebihi dari anggaran yang telah direncanakan.

2. Pos-pos anggaran pengolahan air yang mengalami ketidakefisienan adalah;

Biaya pegawai mengalami selisih pada tahun 2013 terealisir sebesar Rp. 860.799.733 atau $102.02 \%$ dari anggaran $\mathrm{Rp}$. 882.744.738. Ketidakefisienan terjadi pada bulan Januari, Februari, Maret, April, Agustus, Oktober, November, Desember. Walaupun realisasinya tidak terlalu besar dari anggaran, ini masalah perusahaan yang tidak terkontrol. Masih terdapatnya penyimpangan-penyimpangan dalam biaya pegawai yang diluar dugaan. Biaya lembur pegawai menjadi hal utama dalam penyimpangan anggaran. Sehingga pada bulan-bulan tertentu tahun 2013 terjadi selisih anggaran dengan realisasinya..

Biaya Solar terealisir sebesar $109,70 \% \%$ atau Rp. 2.896.170.798 dianggarkan sebesar Rp. 2.640.000.000. Hal tersebut diantaranya disebabkan karena kurangnya pengawasan kepala pengawas terhadap operator alat berat di lapangan, sehingga banyak operator yang nakal memainkan solar. Setiap solar yang di isi tidak di kontrol oleh pengawas, sehingga operator menyedot atau mengambil solar yang ada pada alat berat. Kemudian solar tersebut di jual dan operator mendapatkan keuntungan dari penjuala solar yang di curinya dari alat berat. Oleh karena hal tersebut perusahaan mengalam kerugian dari apa yang di anggarkan tidak terlealisasi sebagaimana yang di rencanakan oleh perusahaan.

Rupa - rupa biaya teralisir 103,34\% atau Rp. 2.946.604.569 dari anggaran Rp. 2.029.127.442 karena adanya penambahan investasi tahun lalu yang terjadi yang nilai bukunya belum di cover pada saat penyusunan anggaran karena rencana anggaran sudah dibuat dan biaya tidak terduga. Anggaran biaya operasional yang di buat perusahaan pasti akan mengalami perbedaan dengan biaya aktual yang sebenarnya dikeluarkan, sebagai bentuk pengendalian manajemen atas penerapan anggaran biaya operasional yang dibuat sebelumnya. Melihat kinerja yang tidak efisien dan melebihi 
dari anggaran maka perusahaan berusaha memaksimalkan kinerja di lapangan sehingga membuahkan hasil yang opsitif dan efisien. Sehingga perusahaan dapat mengantisipasi dalam rencana anggaran periode berikutnya dengan anggaranoperasionai sebagai mekanisme pengendalian dan anggaran lainnya harus dipertimbangkan juga sebagai tambahan atas anggaran.

Anggaran yang disusun oleh tim komisi anggaran masih belum semua biaya yang disesuaikan dengan realisasinya, maka diharapkan untuk rencana anggaran periode selanjutnya dapat sesuai dengan realisasi sehingga hasilnya efektif dan efisien.

\section{DAFTAR PUSTAKA}

Ambarwati, T \& M. Jihadi. 2003. Anggaran Perusahaan. Malang : Universitas Muhamadiyah Malang (UMM Press)

Anthony A. \& Robert S.2004. Akuntansi Biaya, edisi 13. Salemba Empat. Jakarta

Brewer C. Peter, Garrison H. Ray, Norren W. Eric. 2006. Akuntansi Manajerial, edisi 11, Salemba Empat, Jakarta.

Darsono Prawironegoro. 2005. Akuntansi Manajemen. Diadit Media, Jakarta.

Dassler Gary. 2004. Management Principles and Practies for tomorrow's leaders. International Edition, 3 Edition. Pearcon Education, Florida International.

Nafarin, M. 2003. Penggangaran Perusahaan, Salemba Empat, Jakarta.

Don R. Hansen, Maryanne M. Mowen. 2004. Akuntansi Manajemen, edisi 7, Salemba Empat, Jakarta.

Don R. Hansen, Maryanne M. Mowen. 2009. Akuntansi Manajerial, edisi 8 , Salemba Empat, Jakarta.

Hansen, D. R. dan Maryanne M. Mowen. (2006). Akuntansi Manajemen, Edisi 7, Terjemahan Dewi Fitrisari dan Deny Arnos. Jakarta: Salemba

Mulyadi. 2005. Akuntansi Biaya. Edisi 6, STIE YKPN, Jakarta.

Mulyadi.2007. Sistem Perencanaan dan Pengendalian Manajemen. Salemba Empat. Jakarta.

Nafarin, M. 2005. Penggangaran Perusahaan, Salemba Empat, Jakarta. Nafarin, M. 2007. Penggangaran Perusahaan, Salemba Empat, Jakarta.

Sulistiono, A. and Mulyana, M., 2010. Strategi Pengembangan Pemasaran Ukm Pengrajin Sepatu Sandal. Hasil Penelitian Peneliti Muda, Marketing Corner http://mmulyana. wordpress. com, diakses tanggal, 15. 